\title{
The Troubled Future of Colleges and Universities
}

\section{Citation}

King, Gary, and Maya Sen. 2013. The troubled future of colleges and universities. PS: Political Science \& Politics 46, no. 01: 83-89.

\section{Published Version}

doi:10.1017/S1049096512001606

\section{Permanent link}

http://nrs.harvard.edu/urn-3:HUL.InstRepos:11130520

\section{Terms of Use}

This article was downloaded from Harvard University's DASH repository, and is made available under the terms and conditions applicable to Other Posted Material, as set forth at http:// nrs.harvard.edu/urn-3:HUL.InstRepos:dash.current.terms-of-use\#LAA

\section{Share Your Story}

The Harvard community has made this article openly available.

Please share how this access benefits you. Submit a story.

Accessibility 


\title{
The Troubled Future of Colleges and Universities
}

\author{
Gary King, Harvard University \\ Maya Sen, University of Rochester
}

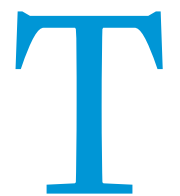

he American system of higher education appears poised for disruptive change of potentially historic proportions due to massive new political, economic, and educational forces that threaten to undermine its business model, governmental support, and operating mission. These forces include dramatic new types of economic competition, difficulties in growing revenue streams as we had in the past, relative declines in philanthropic and government support, actual and likely future political attacks on universities, and some outdated methods of teaching and learning that have been unchanged for hundreds of years.

Most importantly, technological advances, the Internet, quantitative social science (recently known to the general public as "Big Data"), and the computer revolution have massively reinvented or disrupted travel, music, commerce, sports, newspapers, publishing, and many other information-based businesses. Is higher education next? Remember Newsweek? It was also in the business of creating and distributing knowledge. In 2010, the entire company was sold for $\$ 1.00$ (Clark 2010; Vega and Peters 2010).

We think that university officials should now begin to act and with this symposium hope to facilitate a larger conversation about what is happening and what action we might take. In our view, political scientists are uniquely positioned to understand the situation, to study the effects of governmental and economic forces on universities, to analyze the fragile political situation, and to help design new strategies and institutions to respond. It is time the profession engages this crucial issue. If universities fail to rethink their strategic situations and business models, they may well fall to the coming educational "tsunami" (Auletta 2012). Doing nothing different, and imagining that nothing will change, is delusional. Inaction at this point may be as irresponsible to students, faculty, and staff at universities as it is to the country and world that depend on the continuing flow of breathtaking innovations that stem from university research to improve the economy, create wonder, and make the world a better place to live.

\section{THE STATUS QUO BUSINESS MODEL}

The raison d'être of modern universities has long been the (1) creation, (2) preservation, and (3) distribution of knowledge. Universities function best when all three work together. The resulting synergies have produced dramatic progress for hundreds of years: universities are not only the primary stewards of the scientific community but the most sought after way to become educated, a primary driver in reducing income inequality (de Gregorio and Lee 2002), and a major generator of economic growth (Goldin and Katz 2008). These successes have allowed universities to become even more valued for their abilities to create and distribute knowledge.

But how are universities paid for? The business model of most universities relies primarily on tuition revenue from teaching, with some additional funds from sponsored research and philanthropy. However, sponsored research dollars do not even cover their own costs: each year, universities lose between $\$ 700$ million and $\$ 1.5$ billion in administrative and operating costs that are not covered by sponsored federal research grants (Goldman and Williams 200o). For example, the University of California alone reports that it loses approximately $\$ 500$ million each year in unrecouped indirect costs associated with sponsored research (University of California 2012). Given the lack of support in the current political environment for increased funding, and the strict limits placed on indirect costs and overhead, universities shoulder this burden by relying on other sources.

For the top universities, philanthropy is a significant source of funds, and the donors (especially alumni) are extremely loyal citizens of their university-created communities. They will undoubtedly be counted on for much progress going forward. However, overall philanthropic contributions to higher education are down for only the second time since records have been kept, having dropped more than $\$ 400$ million since their peak in 2007-08 (National Center for Education Statistics 2010d). The largest gifts have, of course, historically come from the most wealthy, but among this group giving has dropped significantly both in terms of numbers of donors and numbers of dollars and is far more sensitive to changes in economic conditions. Despite huge increases in the concentration of wealth, giving by the wealthiest donors decreased $9.8 \%$ from 2005 to 2007 , compared to a $1.8 \%$ overall philanthropic decrease (Center on Philanthropy 2009). Even the generous billionaires who have pledged to give away half their money (http://j.mp/ScJN4g) will leave with them a breathtaking concentration of remaining wealth. Empirically, it takes years for wealthy people to learn how to become productive philanthropists, and so universities also struggle with the fact that the increasing numbers of younger wealthy (especially from technology ventures) do not presently give as much as the wealthy from previous eras.

Tuition and fees are paid by students, their families, governments, and endowments, but increasing revenue at the same 
Figure 1

\section{Left: Number of Colleges and Universities in the United States (including branch campuses). Right: Percentage of Enrolled Students at Public, Private, or For-Profit Universities.}

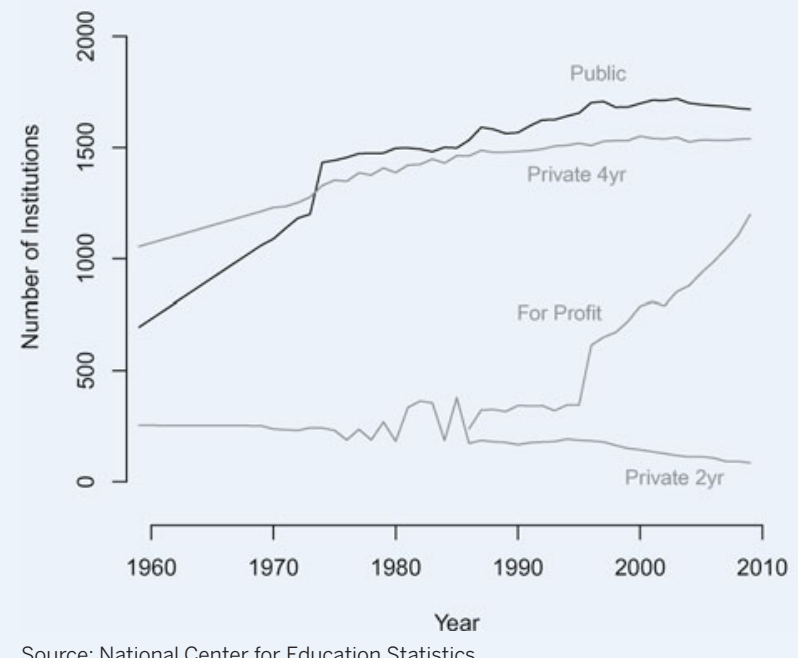

Source: National Center for Education Statistics.

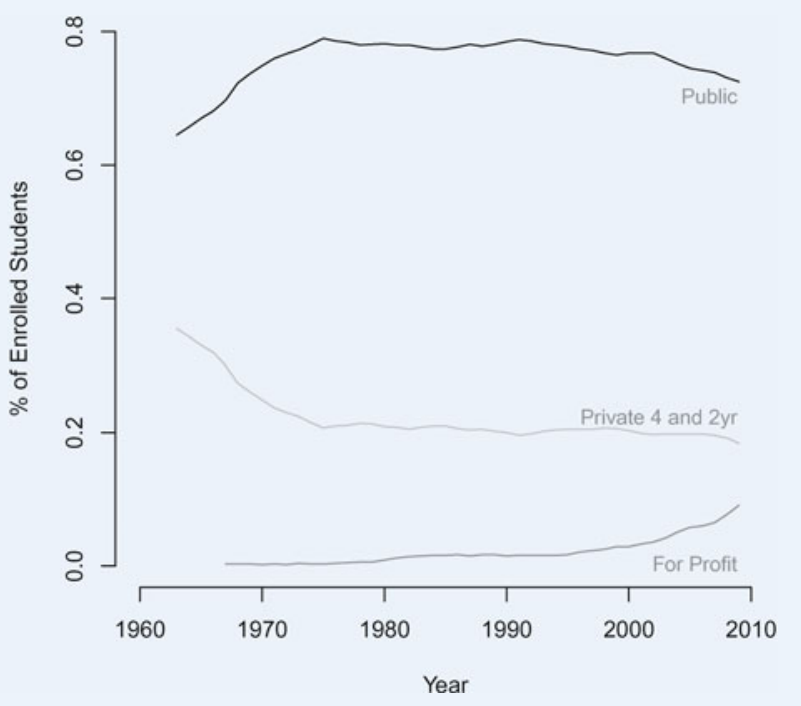

Year rates from these sources seems unlikely. For most of the twentieth century, increasing tuition was a reliable, economically sound way for universities to raise revenue because family incomes were rising. When family incomes stopped rising, as they have for the last two decades (Federal Reserve Board Division of Research and Statistics 2012), federal and state governments intervened by providing basic grants and assistance. Today, tuition is outstripping that assistance, and state and federal budgets are more strained and their legislatures less generous. In addition, academics, especially those receiving federal support (such as in schools of public health), are disproportionately liberal Democrats, and so their ability to stay above the political fray may become more difficult to sustain (Fosse and Gross 2012).

In recent years, families have turned directly or indirectly to home equity loans to pay increasing tuition, but, after the real estate crisis, this is no longer a viable option. Today, many students borrow hefty amounts from private lenders without basic consumer protections. Although this was never planned or expected, student loan debt now even exceeds total credit card debt (Federal Reserve Bank of New York 2012)! The top universities are now charging around a quarter of a million dollars for four years of tuition, and so increasing that much more is likely to be untenable given stagnating family incomes. Universities are also tying their own hands by simultaneously offering more financial aid from their endowments, resulting in larger proportions of endowment payouts being devoted to cover tuition. Even in the midst of the economic recession of 2008, many universities increased their student aid. As laudable as this practice is, it does not help their bottom line. Clearly these paths to growth are all being cut off.
Another way to raise revenue is by admitting more students, which universities consistently did through the early twentieth century (National Center for Education Statistics 2010c). However, at this point, the number of students is relatively fixed because of physical constraints at universities, colleges, and even community colleges (see figure 1); unless universities spend what scarce resources they have on large residential, classroom, and other infrastructure upgrades, meaningfully increasing student enrollments on campus is not feasible. Today even the largest universities are not taking many more students, and private institutions long ago gave up on the idea of increasing enrollments as a way to increase revenue.

\section{ECONOMIC ATTACKS}

We now explore some of the external forces undermining the university business model. In all likelihood, the biggest threat to any university is not another traditional university. After all, when Harvard's or Princeton's endowment surges, so does Stanford's. When the Wisconsin State Legislature cuts the university budget, similar patterns soon follow in California and Ohio. When community colleges in the Northeast are overwhelmed with students and cannot expand to keep up, the same pattern is usually found in the rest of the country. In fact, the relative quality of universities changes little except over the long term, which is, of course, more evidence that universities do not pose much threat to each other. (U.S. News and World Report rankings of universities and departments vary far more from year to year than the quality of these institutions, almost surely because the measurement methods are changed frequently to sell magazines; see Avery et al. 
2004.) To the contrary, academics actually spend a great deal of time helping colleagues in other universities, reviewing each others' programs, writing tenure reviews, serving on visiting committees, and so on. Except perhaps when poaching each other's faculty, they compete but do not usually threaten each other.

Instead, the biggest threat to modern universities comes from four interrelated waves of attack. Together, these four waves have not only fundamentally altered the way that universities operate, but also have substantially changed how and what people around the world learn. Some universities have responded well and absorbed some of these changes, but others have been mostly caught by surprise. All four attacks are going after the main revenue source: teaching revenue. We explore these waves in, more or less, chronological order, although all four continue to have substantial contemporary impact.

Attack \#1: the Internet. The first attack on the traditional brick-and-mortar university came from the Internet, which made knowledge previously attainable only on college campuses available to all. Today, Khan Academy, YouTube Edu, Academic Earth, and other outlets make educational videos available for free; many of these videos cover topics that would be standard in many college curricula, particularly in mathematics, engineering, and science (Kolowich 2011; Sengupta 2011). The Internet also makes it possible for people from all over the world to find practice exams, problem sets, visual examples and walk-throughs, worksheets, lecture notes, academic presentations, interactive exercises, webinars, and more for free. In principle, a villager living in a remote part of China or India can read scholarly papers, practice computer coding, witness scientific experiments, engage in original data gathering, practice mathematics problems, ask follow-up questions in online chat rooms and forums, and solicit feedback from experts and teachers. The Internet has created a community of learners.

The rise of the Internet has perhaps most profoundly affected university libraries. Today, significantly more academic journals and books are available over the Internet than are found in any one university library. Google Books, for example, has scanned some 20 million volumes, establishing a collection that now approximates the size of the US Library of Congress, the world's largest library (Howard 2012). Much of this content comes directly from collections at Harvard, Stanford, and Oxford, which comprise some of the largest university library systems in the world. Putting it most starkly, consider this: if you were creating a university from scratch, would you choose to invest as much in a library system as today's universities have historically done? And would you choose to spend additional money on library buildings, heating and cooling systems, and inventory and access control services, just to maintain a collection that everyone else in the world already has free access to online?

Attack \#2: distance learning. Another wave of attack on the brick-and-mortar universities came in the form of distance learning initiatives beginning in the late 1990 and early 200os. Some grew out of university "extension" or continuing education schools, while others were born out of for-profit companies; some remain, and others have gone bankrupt. But the impact they have made on education is clear: today, around $20 \%$ of all university students take at least one university course online, with 9\% taking all of their courses online (US Department of Education 2011). This is different from the kind of informal Internet-based education we mentioned in the first attack; these are students taking actual courses with actual professors for actual credit with the same credentials as those of traditional universities.

Several institutions now have large for-profit extension or distance operations-for example Harvard's Extension School, New York University's School of Continuing and Professional Studies, and Yale's Continuing Education School. Tenuretrack faculty routinely teach in these programs, which offers students enrolled in distance learning the experience of taking courses with "brand-name" faculty without going through the bother of admissions, tuition and housing expenses, or extra-curricular obligations. (For faculty, teaching via these extension programs means increased enrollment, additional compensation, more exposure, and more teaching assistants-a win-win proposition.)

Attack \#3: for-profit universities. The third wave of attack comes from the still fast growing group of large for-profit (or "career") universities, which have the same accreditation as traditional universities but have the intention and potential to scale up to much larger size.

The rise of for-profit universities in the last 10 years has been staggering (figure 1). Today, about 1,200 for-profit colleges operate in the United States, and they comprise $26 \%$ of all colleges and universities (National Center for Education Statistics 2010a). Indeed, the university with the most enrolled students is not the University of California or the State University of New York. It is the University of Phoenix (Wilson 2011; University of Phoenix 2011). With half a million students, what started out as a small suburban commuter college is now larger than the University of Arizona, Ohio State University, and the University of California combined and about nine times as large as New York University, the largest (mainstream) private university in the country.

For-profit universities have followed a fundamentally different business model than mainstream universities. If modern universities are high-touch operations, with residential programs, in-person teaching experiences, and many extracurricular activities, the for-profits are low-touch operations, without residential campuses but with accessible instructors and teaching assistants. This alternative model, with its lower salaries for teaching staff and the absence of scholarly research operations, is considerably less expensive compared to traditional universities.

This is not to say that the for-profits ignore teaching. The University of Phoenix, for example, spends approximately $\$ 200$ million a year on teaching-related research and development, a figure that dwarfs the investment in teaching made by all the Ivy League combined (Myers 2011). It has invested $\$ 75$ million in an online learning company, developed a Phoenix "Mobile App" for smartphone access, created the "PhoenixConnect" Academic Social Network, and established group-based "Learning Teams" for its students. To be 
fair, this investment is not in social science research about human learning and behavior, but rather applying research to the online environment. It is nevertheless a staggering figure compared to what is sometimes the traditional university's "see no evil, hear no evil, speak no evil" approach to the competition.

Attack \# 4: online start-ups. Fourth, more recently, a wave of education startups like Coursera, Udacity, and Udemy, and a Harvard and MIT spin-off called EdX have formed to provide smaller numbers of courses to massive online audiences. The companies create what have come to be known as MOOCs (massive open online courses), some of which have enrolled as many as 160,00o students (most recently in Stanford's "Artificial Intelligence" class). Whereas traditional universities are high touch and large for-profits are low touch, MOOCs operate in "no touch" mode, where every interaction with students is automated, often with peer interaction, chat rooms, peer review, and automated (or peer) grading. Partisans of traditional universities believe that the in-person experience adds considerable value over this type of online-only education. But how much and under precisely what circumstances has not been fully quantified. Moreover, the widespread impression that MOOCs are isolating experiences for student participants is flat wrong: student participants all over the world spontaneously join together into study groups, simulated classrooms, and other joint learning experiences, and this does not even count the automated ways of encouraging students to interact (Duneier 2012). industry realized. Learning comes in many forms; clearly this innovation has barely begun to take shape.

\section{POLITICAL PROBLEMS}

The current economic situation is troubling, but the political situation is hardly more promising. We might ask first whether it is reasonable to think that our elected officials will save traditional universities. After all, in recent years, members of Congress have been battering the leaders of for-profit universities for taking unfair advantage of federal financial aid and students, often convincing students to take out loans for programs with very low graduation and job placement rates. Some university officials scoff at the for-profits, thinking that they have gotten their comeuppance and so the threat has subsided (and indeed private equity investments did sharply drop). However, political scientists should recognize that this as merely an example of successful rent-seeking behavior: although the most extreme abuses are being eliminated, these companies have found a stable, predictable, and locked-in source of US government funds. Some of these funds previously went to traditional universities, and some are new, but either way the political situation is not favorable.

But an even more serious problem is coming. Traditional universities have long been proud to admit and train only the best students. These students certainly make the environment better for learning, but we can think about this differently: the goal of most universities has been to educate only the most educationally advantaged students, for which our

\section{Making progress in studying and influencing higher education requires an understanding of government, policy, politics, human behavior, institutions, conflict, social organization, and economic forces-which means that political scientists have much to offer in understanding the new landscape.}

Although recent quantitative comparisons have concluded the opposite (Means et al. 2010), it seems reasonable to assume that researchers will eventually be able to document the benefits of in-person over online education. But if so, will these benefits persist? What are the benefits of taking four courses in the same semester from the best professors at four different universities, without travel and at far lower cost? Could extracurricular activities go online, too? Eventually, when immersive video technology is good enough so that we can go out to dinner at different restaurants but still have the experience of dining together, it is difficult to see what could not be put online.

MOOCs are still in their infancy. Today, many more students start these courses than finish, and an astonishingly low percentage do what it takes to get any type of formal record (credit, badges, certifications, etc.) of having completed the course. This may mean that MOOCs are closer to entertainment than education, a sort of TED.com on steroids, and we may instead be learning that people enjoy leisure activities with intellectual stimulation more than the entertainment deeply held diversity norms are rarely applied. Indeed, the implicit theory here is trickle-down education: if we select the best, train them to be better, and send them out to the undifferentiated and uneducated masses, they will make a difference, not only for themselves but for all the others not fortunate enough to attend college. If this claim is true, is it politically sustainable?

Here's the political problem: in 2012, only about $30 \%$ of Americans are getting college degrees (US Census Bureau 2012). This leaves approximately $70 \%$ of the population shut out of the American system of higher education, resulting in a huge and growing economic divide between the educational haves and have-nots (Dillon 2007).

One reasonable speculation informed by political science is that this issue will be adopted by some enterprising politician. It could be a progressive wanting more people to get college degrees or a populist trying to bring education to the masses. To this politician, traditional universities have no bandwidth to help, and might well be the enemy. But it could also be a conservative Republican, fed up with universities 
filled with liberals serving, or maybe even creating, other liberals. Or it could be a member of either party merely trying to increase overall wealth. Economists have demonstrated that the massive increases in income inequality since the 1970 are largely due to the growth in education not keeping up (Goldin and Katz 2008) or, to put it another way, due to the failures of traditional colleges and universities in serving the broader American population. The issue could even be adopted by a libertarian who wants to make room for businesses trying to serve the $70 \%$ without degrees and upset that the government pays a fortune to subsidize only one segment of the industry. Whoever adopts the issue, and whatever the policy prescription, having the potential for 7 in 10 Americans to benefit would seem to make it a winning political issue, even though it does not benefit traditional universities. Universities clearly have not anticipated the problem and may not be able to respond; they are not ready to increase their student bodies and have no plans to make it possible (Lawton and Katsomitros 2011).
Second, other universities have actively sought to develop branch campuses overseas. Prominent examples include New York University's campus in Abu Dhabi, Yale's campus in Singapore, and Duke's attempt to open a campus in the United Arab Emirates. (In contrast, prominent failures include the Michigan State and George Mason University Middle East campuses.) This strategy is expensive, however, and does little to help the $70 \%$ of Americans locked out of higher education.

Third, the number of mainstream universities has increased during the last 60 years, but the growth has slowed substantially over the past 30 (figure 1). Today, as many public universities, private colleges, and two-year colleges exist as did 35 years ago. The greatest growth during the past 30 years has come from for-profit colleges.

Finally, universities have moved toward generous financial aid policies, and increasing numbers of students are receiving some sort of financial aid (National Center for Education Statistics 2010b). Although this action has changed the pop-

\section{Ultimately, humans tend to regard anything standing still for a while as permanent, and they are often surprised when stasis is followed by a sharp change. Universities, colleges, and society at large will be much better off if we can learn to act in anticipation rather than waiting for the change to define us.}

The paradox is that the biggest supporters for expanding the educational franchise and supporting the competitors of traditional universities may well be those within traditional universities. After all, most officials at traditional universities, their boards of trustees, and their faculties are extremely liberal relative to the national electorate. We can see this reflected in sociological studies of faculty (Fosse and Gross 2012), generous university financial aid policies, progressive Affirmative Action policies, aggressive attempts to recruit minorities and economically disadvantaged students, and considerable efforts to keep students from dropping out. Indeed, although they are presently unabashedly in favor of biasing their institutions toward the educationally advantaged, university administrators are highly committed to diversity based on many other variables, such as race, ethnicity, gender, sexual orientation, age, ideological persuasion, geographic and national origin, and academic interests.

\section{INADEQUATE UNIVERSITY RESPONSES}

Universities have responded in at least four ways, all important, but none that would lead to an increase in the numbers of students educated or a more sustainable business model. First, as we noted, some have gone after the untapped market of educationally disadvantaged students by establishing extension or distance components-Harvard's Extension School, New York University's School of Continuing and Professional Studies, and Yale's Continuing Education School. However, the largest of these is tiny compared to the for-profits, much less the MOOCs. ulation of students who can feasibly attend, it has not greatly increased their numbers or made it possible for educationally disadvantaged students to attend.

\section{WHAT SHOULD WE DO?}

Making progress in studying and influencing higher education requires an understanding of government, policy, politics, human behavior, institutions, conflict, social organization, and economic forces-which means that political scientists have much to offer in understanding the new landscape. A vast and important opportunity exists for using the theories, approaches, and methods of analysis of our discipline. The results could be measured in knowledge learned but also in the possibly of doing a great deal of good for those who have devoted their lives to higher education, to prospective students everywhere, and to society at large.

In our view it is time to study and to act. We offer here a few initial suggestions on how the profession might get started. First, we can build on our tremendous advantage in research to improve teaching and learning. Whereas universities have always produced among the best research, their new competitors don't even try and are not positioned to change that any time soon. That means that the research-teaching synergy that we have benefited from all these years is not available to them. To make progress, we should apply social science research to revamp university pedagogy. Huge advances in social science and psychology have changed the way we understand the human mind and learning; but, despite this revolution, most college lectures have not changed, literally, in millennia. It is 
time to incorporate social science research into our pedagogy. This can include leveraging social networks; introducing, evaluating, and improving peer instruction, team-based learning and other collaborative approaches; and building better automated tools to educate large numbers of students. We offered some ideas along these lines in King and Sen (2012).

Second, although we have a tremendous advantage in educating the educationally advantaged, we need to reach out and learn how to educate other types of students. To learn how to do this, universities need to educate more students of more types. Our physical campuses may be the best way to have some types of impact, but today's technological changes are making it possible to educate (and learn from) large numbers of not-so-advantaged students even when they are not on campus. Some universities have already started: they are expanding their distance learning offerings (Korkii 2012; Jaschik 2009), forming partnerships with some of the new startups (Markoff 2012), and creating their own startups (Lewin 2012). Thus far, these are small experiments, affecting relatively small numbers of students, but we might look for ways of greatly expanding them.

Third, universities should flex their traditional dominance over the creation and preservation of knowledgeeven if their role as sole distributors of knowledge is under attack. We should change the university from a place where knowledge learned outside the classroom is reported to students to one where students themselves directly experience having a hand in creating knowledge. It is a travesty for a student to spend four years at a world-class university and only read about major discoveries in the campus newspaper.Just as spending a semester in a foreign country can change your life, having a seat at the table when a major discovery is made can also be life-changing. Many university faculty are terrific teachers, but those who survive excel at research, are motivated by research, and earned their position in the university because of their research; we should give students that same experience. We should lead with what we are good at, which is in large part research. All research groups on campus should strive to have some type of participation by students or apprenticeship component. This experience students cannot get at any of the forprofit competitors, and although university faculty often love to teach, what gets them up in the morning and keeps them fascinated with their subject matter is the thrill of discovery and invention. Is there a more meaningful gift we can give our students?

Of course, these are just a few possibilities. We hope the discussion that follows reveals other strategies, perspectives, and plans for action. Ultimately, humans tend to regard anything standing still for a while as permanent, and they are often surprised when stasis is followed by a sharp change. Universities, colleges, and society at large will be much better off if we can learn to act in anticipation rather than waiting for the change to define us.

\section{ACKNOWLEDGMENTS}

Our thanks to Clayton Nall, Stanford University, and Mike Smith, Harvard University, for many insightful thoughts, and to comments at a meeting of the Harvard Board of Overseers.

\section{REF EREN C ES}

Auletta, Ken. 2012. "Get Rich U.” The New Yorker. http://j.mp/JvzQQE, April 30.

Avery, Christopher, Mark Glickman, Caroline Hoxby, and Andrew Metrick. 2004. A revealed preference ranking of US colleges and universities. Technical report National Bureau of Economic Research.

Center on Philanthropy. 2009. "The 2008 Study of High Net Worth Philanthropy: Issues Driving Charitable Activities among Affluent Households." http://www.philanthropynw.org/s_pnw/bin.asp?CID =6396\&DID = $26397 \&$ DOC $=$ FILE.PDF.

Clark, Andrew. 2010. "US Tycoon Sidney Harman Buys Newsweek 'For a Dollar'.” http://www.guardian.co.uk/media/2010/aug/o3/sidney-harmanbuys-newsweek-magazine.

de Gregorio, Jose, and Jong-Wha Lee. 2002. "Education and Income Inequality: New Evidence from Cross-Country Data." Review of Income and Wealth 48 (3): 395-416.

Dillon, Sam. 2007. "Troubles Grow for a University Built on Profits.” New York Times 2/11/2007.

Duneier, Mitchell. 2012. "Teaching to the World from Central New Jersey." Chronicle of Higher Education (3 September). http://j.mp/UCvJU8.

Federal Reserve Bank of New York. 2012. "Quarterly Report on Household Debt and Credit." http://www.newyorkfed.org/research/national_economy/ householdcredit/DistrictReport_Q42011.pdf.

Federal Reserve Board Division of Research and Statistics. 2012. "Changes in U.S. Family Finances from 2007 to 2010: Evidence from the Survey of Consumer Finances." http://federalreserve.gov/pubs/bulletin/2012/PDF/ scf12.pdf.

Fosse, Ethan, and Neil Gross. 2012. "Why are Professors Liberal?" Theory and Society pp. 1-42

Goldin, Claudia and Lawrence F. Katz. 2008. The Race between Education and Technology. Cambridge, MA: Harvard University Press.

Goldman, Charles A. and T. Williams. 20oo. "Paying for University Research Facilities and Administration." http://www.rand.org/pubs/monograph_ reports/MR1135-1.html.

Howard, Jennifer. 2012. "Google Begins to Scale Back Its Scanning of Books from University Libraries." http://chronicle.com/article/Google-Begins-toScale-Back/131109.

Jaschik, Scott. 2009. "Rise in Distance Enrollments." http://www. insidehighered.com/news/2009/04/06/distance.

King, Gary, and Maya Sen. 2012. "How Social Science Research Can Improve Teaching." http://j.mp/NFVja6.

Kolowich, Steve. 2011. “The Problem Solvers.” http://www.insidehighered. com/news/2011/12/o7/khan-academy-ponders-what-it-can-teach-highereducation-establishment.

Korkii, Phyllis. 2012. "More Courses Get You Ready to Face the World.” http:/ www.nytimes.com/2012/o3/o1/education/continuing-education-programsexpand-global-focus.html.

Lawton, William, and Alex Katsomitros. 2011. "International branch campuses expanding, geopolitical landscape changing." http://www. universityworldnews.com/article.php?story $=20120118205237531$

Lewin, Tamar. 2012. "Harvard and M.I.T. Team Up to Offer Free Online Courses." http://www.nytimes.com/2012/05/o3/education/harvard-andmit-team-up-to-offer-free-online-courses.html.

Markoff, John. 2012. "Online Education Venture Lures Cash Infusion and Deals With 5 Top Universities.” http://www.nytimes.com/2012/04/18/ technology/14coursera-plans-to-announce-university-partners-for-onlineclasses.html.

Means, Barbara, Yukie Toyama, Robert Murphy, Marianne Bakia, and Karla Jones. 2010. "Evaluation of Evidence-Based Practices in Online Learning A Meta-Analysis and Review of Online Learning Studies." Technical Report, US Department of Education.

Myers, C.B. 2011. "Clayton Christensen: Why Online Education is Ready for Disruption, Now." http://thenextweb.com/insider/2011/11/13/claytonchristensen-why-online-education-is-ready-for-disruption-now/.

National Center for Education Statistics. 2010a. "Degree-Granting Institutions, by Control and Type of Institution: Selected Years, 1949-50 through 2009-10." http://nces.ed.gov/programs/digest/d10/tables/ dt10_275.asp?referrer $=$ list. 
National Center for Education Statistics. 2010b. "Full-Time, First-Time Degree/Certificate Seeking Undergraduate Students Enrolled in DegreeGranting Institutions, by Participation and Average Amount Awarded in Financial Aid Programs, and Type and Control of Institution: 2000-01 through 2008-09." http://nces.ed.gov/programs/digest/d1o/tables/ dt10_350.asp.

National Center for Education Statistics. 2010c. "Total Fall Enrollment in Degree-Granting Institutions, by Attendance Status, Sex of Student, and Control of Institution: Selected Years, 1947 through 2009." http:// nces.ed.gov/programs/digest/d10/tables/dt10_197.asp?referrer=list.

National Center for Education Statistics. 2010d. "Voluntary Support for Degree-Granting Institutions, by Source and Purpose of Support: Selected Years, 1959-6o through 2008-09." http://nces.ed.gov/programs/digest/d1o/ tables/dt10_371.asp?referrer=list.

Sengupta, Somini. 2011. "Grading the Digital School: Online Learning, Personalized." http://www.nytimes.com/2011/12/05/technology/khanacademy-blends-its-youtube-approach-with-classrooms.html.
University of California. 2012. "Working Smarter: Indirect Cost Recovery." http://workingsmarter.universityofcalifornia.edu/projects/indirect-costrecovery/case-study/.

University of Phoenix. 2011. "University of Phoenix Third Annual Academic Report." http://cdn.assets-phoenix.net/content/dam/altcloud/doc/ about_uopx/academic-annual-report-2010.pdf.

US Census Bureau. 2012. "2012 Statistical Abstract of the United States: Educational Attainment by Race and Hispanic Origin, 1970 to 2010." http://www.census.gov/compendia/statab/2012/tables/12s0229.pdf.

US Department of Education. 2011. "The Condition of Education 2011 (NCES 2011-033)." http://nces.ed.gov/fastfacts/display.asp?id=8o.

Vega, Tanzina, and J. Peters. 2010. "Audio Pioneer Buys Newsweek.” http:// www.nytimes.com/2010/o8/o3/business/media/oznewsweek.html.

Wilson, Robin. 2011. "For-Profit Colleges Change Higher Education's Landscape Nimble Companies Gain a Fast-Growing Share of Enrollments." The Chronicle of Higher Education. http://chronicle.com/article/For-ProfitColleges-Change-/64012/. 